\title{
Cotton (Gossypium hirsutum L.) Boll Rot and Associated Microorganisms in South Texas Fields
}

\author{
Greta Schuster $^{1 *}$, Enrique G. Medrano ${ }^{2 *}$, Kendal Field-Huey ${ }^{1}$ \\ ${ }^{1}$ Texas A\&M University, Kingsville, TX, USA \\ ${ }^{2}$ United States Department of Agriculture, Agricultural Research Service, College Station, TX, USA \\ Email: ${ }^{\star}$ Greta.Schuster@tamuk.edu, ${ }^{\star}$ ginomedrano@ars.usda.gov
}

How to cite this paper: Schuster, G., Medrano, E.G. and Field-Huey, K. (2016) Cotton (Gossypium hirsutum L.) Boll Rot and Associated Microorganisms in South Texas Fields. Agricultural Sciences, 7, 732-746. http://dx.doi.org/10.4236/as.2016.710068

Received: September 17, 2016

Accepted: October 24, 2016

Published: October 27, 2016

Copyright (c) 2016 by authors and Scientific Research Publishing Inc. This work is licensed under the Creative Commons Attribution International License (CC BY 4.0).

http://creativecommons.org/licenses/by/4.0/

\begin{abstract}
A rise in cotton boll rot in south Texas has been generally associated with increased yield losses. Here, we measured boll rot incidence during two growing seasons (2011 and 2012) at a south Texas (Kleberg County) research farm Variety Trial and in producer fields. The Variety Trial was conducted to compare boll rot susceptibility between five current cultivars. The commercial fields surveyed were located along the Coastal Bend (Wharton County) and Rio Grande Valley regions (Cameron and Willacy Counties). Bolls with evidence of external damage potentially inflicted by piercing-sucking insect vectors were dissected for disease detection and plated for microorganism isolation and characterization. Microbial isolates were putatively identified based on standard fatty acid methyl ester profile analysis. In the Variety Trial, the highest incidence of disease occurred in July for both growing seasons, and significant differences in susceptibility to boll rot between cultivars were determined $(\mathrm{P}<0.05)$. The highest boll disease incidence was $28 \%$ in August 2012 for the Coastal Bend region and also 28\% but in June 2011 in the Rio Grande Valley. Bacillus species were predominately isolated and associated with boll rot for all the fields studied over the 2 year period. This is the first report to directly study the occurrence of boll rot in south Texas and associate Bacillus spp. as a potential and prevalent causative agent(s).
\end{abstract}

\section{Keywords}

Subtropical Agriculture, Cotton Varieties, Boll Rot, Bacterial Opportunist, Insect Vector

\section{Introduction}

Cotton (Gossypium hirsutum L.) is a major fiber crop grown worldwide including in 
the United States, China, Australia, India, Egypt, and African tropics [1]. In 2010, the United States harvested 10.7 million cotton acres with Texas producing over half of that total acreage [2]. In Texas, cotton is the leading cash crop grown on over 5 million acres [3]. In 2016, the cotton acreage planted is predicted to increase by about $6 \%$ [4]. The south Texas Coastal Bend and Rio Grande Valley regions produce approximately $11 \%$ of the state's total cotton crop [3].

Loss of cotton due to boll rot varies from year to year presumably due to weather conditions, insect vector pressure, pathogen presence, and geographic location [5] [6] [7] [8]. Between 2010 and 2011 there was an estimated yield loss of 100,153 to 182,708 bales of US cotton due to boll rot [9] [10] and the trend has since continued. Boll rot is a term used to describe various symptoms or reactions to infections by various plant pathogenic microorganisms affecting developing cotton bolls [11]. Beginning in 1999, a non-traditional rot has had a significant negative economic impact in US cotton yields [12] [13]. Disease symptoms occur primarily in the inner boll with the outer boll inconsistently symptomatic. The inner boll infection was reportedly associated with opportunistic bacteria with Pantoea agglomerans as the main agent in certain regions [14] [15] [16].

The objectives of this study were to measure the prevalence and incidence of boll rot, and putatively identify the microbial isolates associated with the disease and determine their pathogenicity. A variety trial was planted to determine if there was a difference in susceptibility of cotton boll rot between different cotton cultivars. Additionally, commercially produced cotton fields in the Coastal Bend and Rio Grande Valley were surveyed to regionally determine the distribution of boll rot. This baseline study is the first to specifically chronicle boll rot to in the region. Ultimately, this work will assist in understanding infection dynamics for development of a predictive infection model for use as guidance by producers to minimize yield losses to this malady.

\section{Materials and Methods}

\subsection{Cotton Plants}

The variety trials were grown at the Texas A\&M University, Kingsville (TAMUK) Research Farm in Kleberg County. The five commercial varieties of cotton used included Fiber Max (FM) 840B2F, FM 1740B2F, Delta Pine (DP) 1048B2RF, DP 1044 B2RF, and Phytogen (PHY) 375. Cotton seed were planted in March for both 2011 and 2012. In 2011, four rows of each variety were planted in a randomized complete block design, replicated three times on $76 \mathrm{~cm}$ beds. In 2012, four rows of each variety were planted in a randomized complete block design, replicated four times on $90 \mathrm{~cm}$ rows. All plots had a seeding rate of $4-5$ seeds per $30 \mathrm{~cm}$ ( 3600 plants total in a plot).

Limited furrow irrigation was provided throughout both years to assist with crop development. Glyphosate herbicide (Agri Supply ${ }^{\oplus}$, Garner, NC, USA) was applied both years late April by an over-the-top application at the $4-5$ leaf stage at $0.65 \mathrm{ml}$ per acre for weed control and supplemented with manual picking. Daily meteorological data collected by the National Weather Service's National Oceanic and Atmospheric Ad- 
ministration (www.noaa.gov) was used in the study.

The commercial fields were located in a Coastal Bend county (Wharton) and two Rio Grande Valley counties (Cameron and Willacy). Producer fields were planted and maintained by owners according to their specifications. Bolls were collected with the farmer's permission.

\subsection{Boll Collections}

In both seasons and from all fields, bolls with apparent damage by insect pests that feed using a piercing-sucking mechanism (i.e. stink bugs, plant bugs, etc.) were collected periodically following first bloom beginning in June and continuing through August. Evidence of insect feeding included dark colored, sunken lesions on the outer wall. Damaged bolls were randomly collected leaving $3 \mathrm{~cm}$ of the petiole attached after entering $6 \mathrm{~m}$ into the field and sampling every 10 - 15 paces. Depending on damage incidence at least 40 bolls per field were collected and all samples were transported to the TAMUK laboratory for analysis.

\subsection{Cotton Boll Analysis}

Boll processing procedures essentially followed Medrano et al. [17]. Briefly, the petiole and bracts were discarded, and the bolls were placed in a $10 \%$ sodium hypochloride solution for $10 \mathrm{~min}$ with stirring every $2 \mathrm{~min}$, and then rinsed in water for $5 \mathrm{~min}$. With an alcohol dipped and flamed sterilized razor blade, the peduncle and boll apex were cut and discarded. An incision was made between each suture of the boll to separate the boll into its component locules ( 3 - 5 per fruit). Sterile forceps were used to separate the locule from the boll wall. The inner boll wall was inspected for sucking insect puncture wounds, and the seed and lint observed for disease symptoms. Boll locules were scored using a scale system ranging from 0 - 4 . The scale consisted of 0 (no disease symptoms), 1 ( 1 to $24 \%$ disease), 2 ( 25 to $49 \%$ ), 3 (50 to $74 \%$ ), and 4 (75 to 100\%) (Figures 1 (a)(d)). Approximately $0.5 \mathrm{~g}$ of damaged seed with attached lint was triturated in $1 \mathrm{ml}$ of sterile water and 10-fold dilution plated on Tryptic Soy Agar (TSA; St. Louis, MO). Microbe growth was assessed following an incubation period of $48 \mathrm{~h}$ at $27^{\circ} \mathrm{C}$ in darkness. Remote colonies were purified and stored in glycerol using methods described in Medrano and Bell [18]. Identification using Fatty Acid Methyl Ester (FAME) profile analysis [19] was conducted at the Texas Plant Disease Diagnostic Lab (TPDDL) in College Station, TX. Putative species identification was determined by match to the Sherlock Version 4.5 (0209B); TSBA 404.10 library as measured by the Similarity (SIM) index to the database for bacteria. Only matches that were greater than $70 \%$ were considered acceptable to genus categorization for this study.

\subsection{Pathogenicity Testing}

Cotton plants (DeltaPine 1555) were grown and maintained in a greenhouse following the methods described in Medrano and Bell [18]. Bolls that were at a maturity of $12-16$ days were used in infection tests. Commonly isolated bacteria were chosen for pathoge- 


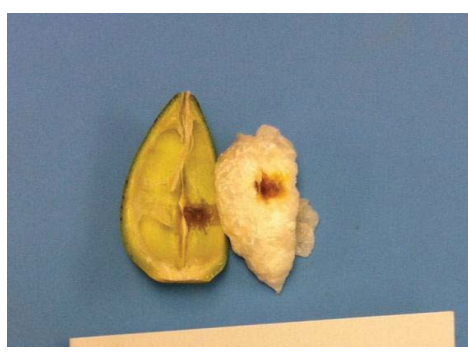

(a)

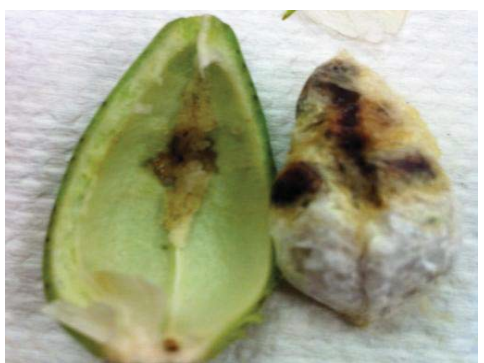

(c)

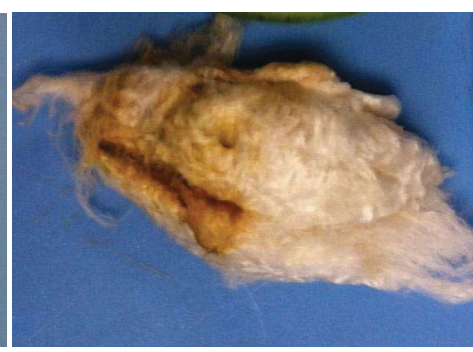

(b)

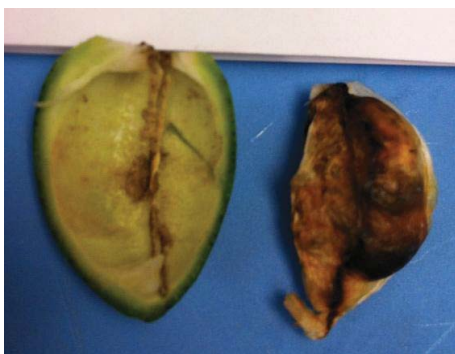

(d)

Figure 1. Field collected bolls with various degrees of disease were scored using a scale system ranging from 0 - 5. The scale consisted of 0 (no disease symptoms) - not pictured, 1 ( 1 to $24 \%$ disease) - 1(a), 2 (25 to $49 \%)-1$ (b), 3 (50 to $74 \%)-1(\mathrm{c})$, and 4 (75 to $100 \%)-1(\mathrm{~d})$.

nicity testing. Water suspensions of $18 \mathrm{~h}$ TSA grown cultures were adjusted spectrophotometrically $\left(A_{600}=0.5\right)$. In triplicate, one boll per isolate was inoculated into the suture at a final concentration of $10^{3}$ cells using a 31 gauge needle and syringe. A positive control consisted of boll inoculations with Pantoeaagglomerans strain Sc 1-R that is a documented boll rot pathogen vectored by piercing-sucking stink bugs [15]. Water inoculations were used as negative controls. Two weeks after inoculating, boll were harvested and rated for severity symptoms.

\subsection{Statistical Analysis}

Data analyses were conducted in Statistical Analysis System (SAS) Version 9 [20]. The GLM procedure was run among individual sampling locations with dependent variables being means of punctures per locule in a boll and disease to identify interactions between cotton varieties and collection dates, and to identify means of varieties and collection dates protected by Least Significant Differences (LSD) lines. Additionally, an analysis was conducted to identify any significant differences amongst the dependent variable, locations, within the independent variables, varieties, puncture per locule in a boll, and disease. LSD lines protected means of location, variety, and collection dates with confidence levels considered significant at $\mathrm{P} \leq 0.10$.

\section{Results and Discussion}

\subsection{Cotton Boll Collections}

Variety Trial-Kleberg County, TX research farm. In the 2011, 550 bolls were col- 
lected and dissected. Boll rot was observed throughout the season. The highest boll rot incidence was $67 \%$ from the pooled variety collections (Table 1). In 2012, 800 bolls were analyzed and rot was observed throughout the season reaching 23\% (Table 1). Interestingly, during both years boll rot was the highest during the first week of July which may be related to early boll developmental stage susceptibility.

From the 2011 growing season significant differences were observed in the number of punctures per locule in a boll over collection dates and among trial varieties (Figure 2 and Figure 3). Punctures per locule from the first collection date were significantly lower than the later samples $(\mathrm{P}<0.10$, Figure 2$)$. There was a 1.4 increase in the number of punctures/locule observed between 20 June $(\mu=0.42)$ and 7 July $(\mu=1.8)$. A slight increase in mean punctures/locule were observed on 22 July, with another increase on 28 July, followed by a slight decrease in the amount of punctures per locule observed in bolls collected on 4 August 2011.

Table 1. Variety trial (Kleberg County, TX) boll damage and percent disease incidence.

\begin{tabular}{cccc}
\hline Sample Date & Sample Size & Bolls with Internal Damage & Incidence* \\
\hline $6 / 20 / 2011$ & 251 & 59 & $24 \%$ \\
$7 / 06 / 2011$ & 52 & 35 & $67 \%$ \\
$7 / 22 / 2011$ & 118 & 55 & $47 \%$ \\
$7 / 28 / 2011$ & 79 & 50 & $63 \%$ \\
$8 / 04 / 2011$ & 50 & 28 & $56 \%$ \\
$6 / 11 / 2012$ & 200 & 25 & $13 \%$ \\
$6 / 19 / 2012$ & 200 & 39 & $20 \%$ \\
$6 / 28 / 2012$ & 200 & 29 & $15 \%$ \\
$7 / 03 / 2012$ & 200 & 46 & $23 \%$ \\
\hline
\end{tabular}

${ }^{*}$ Percent incidence determined by bolls with internal damage $\div$ sample size $\times 100$.

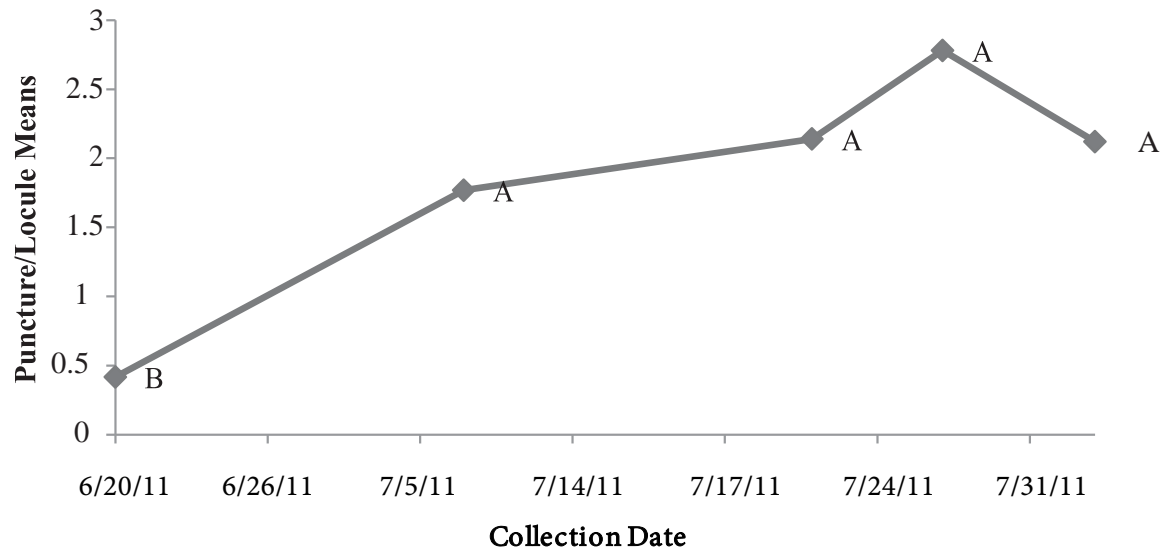

Figure 2. Cotton boll punctures per locule from the Variety Trial sampled during $2011(\mathrm{P}=$ $0.09)$. 
Significant differences were observed in the number of boll punctures per locule between varieties during the 2011growing season $(\mathrm{P}<0.10)$. FM 840B2F $(\mu=0.89)$ was statistically different than DP 1048B2RF $(\mu=2.06)$ and FM 1740B2F $(\mu=2.03)$ (Figure $3)$. There was an average of no more than 2 punctures per locule observed on cotton bolls collected from all five of the varieties in the trial. This generally suggested that although insect pressure was apparently low, those present favored feeding on a particular varieties.

The number of punctures per locule in cotton bolls in 2012 were significantly different $(\mathrm{P}<0.10)$ particularly between the collections from 19 June $2012(\mu=0.28), 28$ June $2012(\mu=0.71)$, and 3 July $2012(\mu=1.2)$ (Figure 4$)$. No significant difference was observed among puncture per locules between varieties in $2012(\mathrm{P}=0.98)$. Interestingly, there was less than 1 puncture per locule on average in cotton bolls that were collected in the variety trial.

Generally, punctures per locule in 2012 were less than in 2011. In 2011, an average of 2 punctures per locule was observed in collected bolls compared to the less than 1

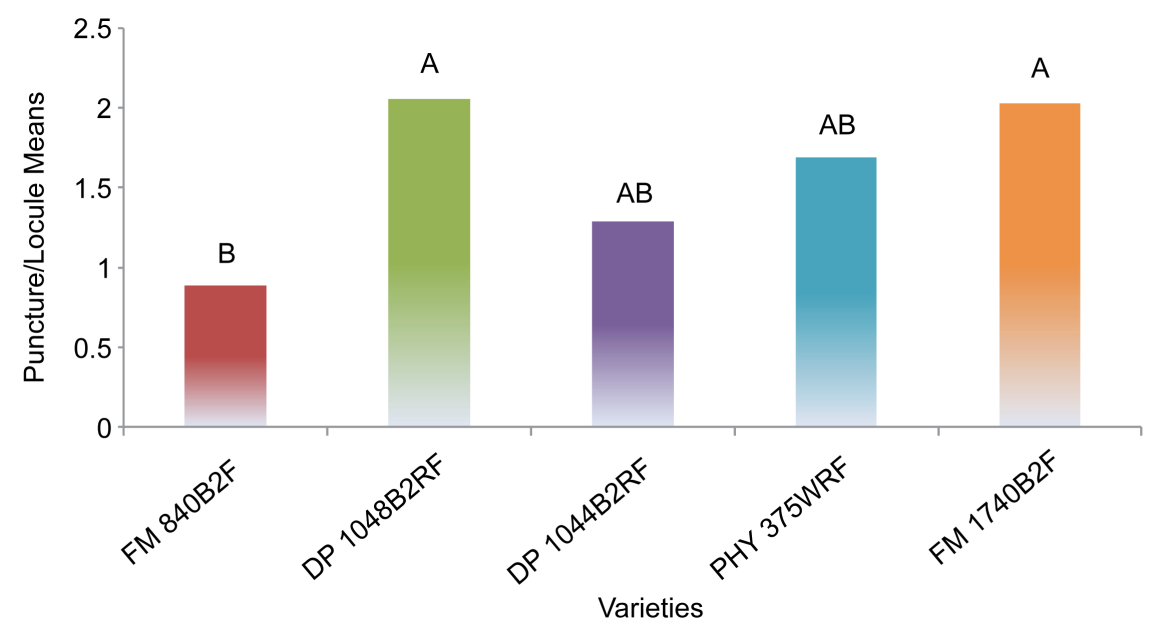

Figure 3. Cotton boll punctures per locule by cultivar during the 2011 Variety Trial $(\mathrm{P}=0.07)$.

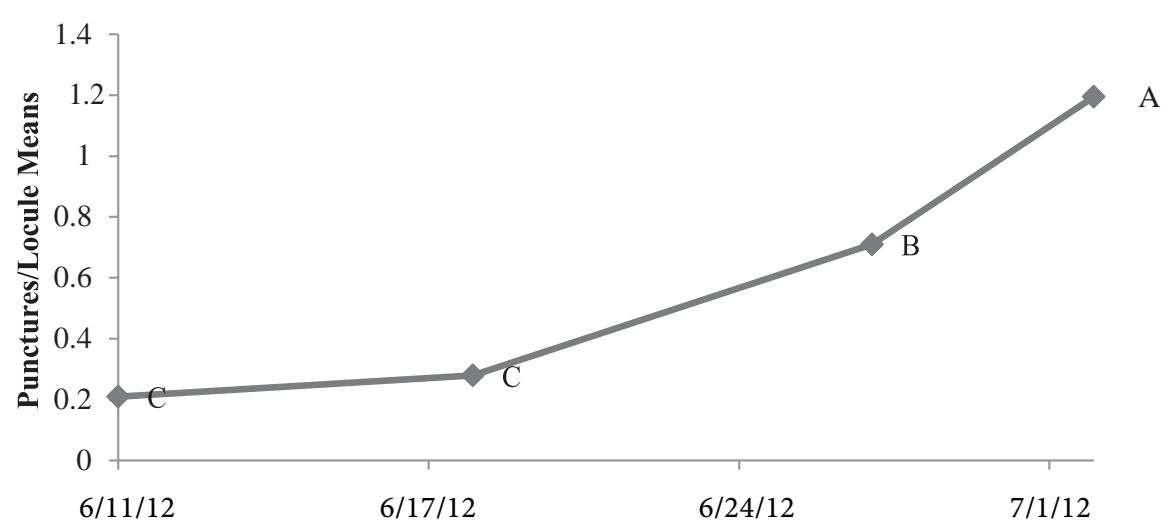

Collection Date

Figure 4. Cotton boll punctures per locule from the 2012 Variety Trial samples $(\mathrm{P}=0.0001)$. 
puncture per locule in 2012. Based on the means among trial varieties for both years, there was likely a pest pressure difference between the seasons. The difference may be associated with cotton being the only crop in the field in 2011 as compared to 2012 when sorghum was also planted in the Kleberg county research farm.

There was a significant $(\mathrm{P}<0.1)$ increase in the severity of disease observed from 19 June ( $\mu=0.13)$ to 28 June 2011 ( $\mu=0.45$; Figure 5$)$ from the overall Variety Trial collection. Statistically significant differences were calculated in the severity of disease between varieties in 2011 ( $\mathrm{P}<0.1$, Figure 6). Specifically, DP 1048B2RF $(\mu=0.6)$ had a significantly higher disease incidence than DP 1044B2RF ( $\mu=0.3$, Figure 6$)$. The average severity of disease observed was equal to one and thus, low among the bolls collected from the varieties. The difference in boll susceptibility to disease based on the cotton variety could be used to determine which types are best suited for the region.

Disease severity was not significantly different during the 2012 overall boll collect data from the Variety Trial ( $\mathrm{P}=0.5327$, Figure 7). Throughout the 2012 season disease severity was relatively low, with the 3 July collection $(\mu=0.14)$ exhibiting the

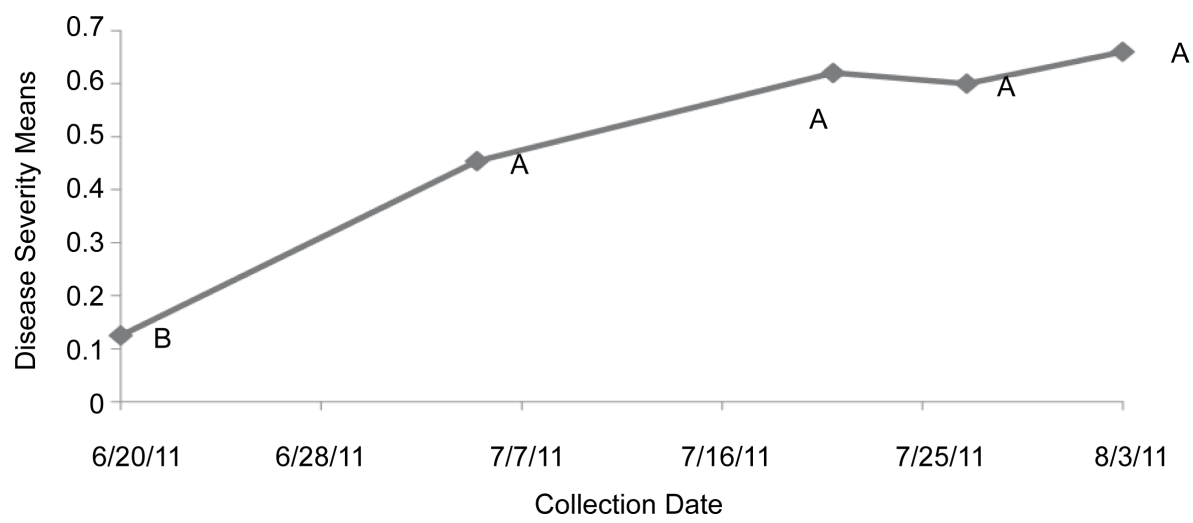

Figure 5. Disease severity in cotton bolls from the 2011 Variety Trial $(P=0.0002)$.

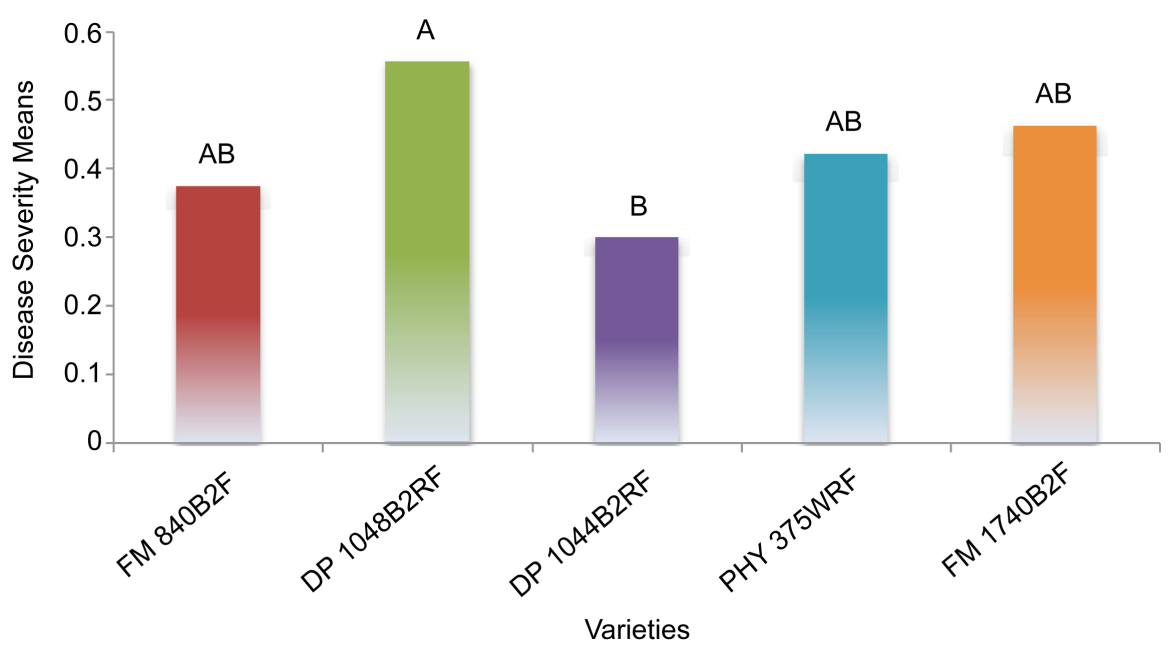

Figure 6. Disease severity in cotton bolls by cultivar during the 2011 the Variety Trial $(\mathrm{P}=$ $0.025)$. 


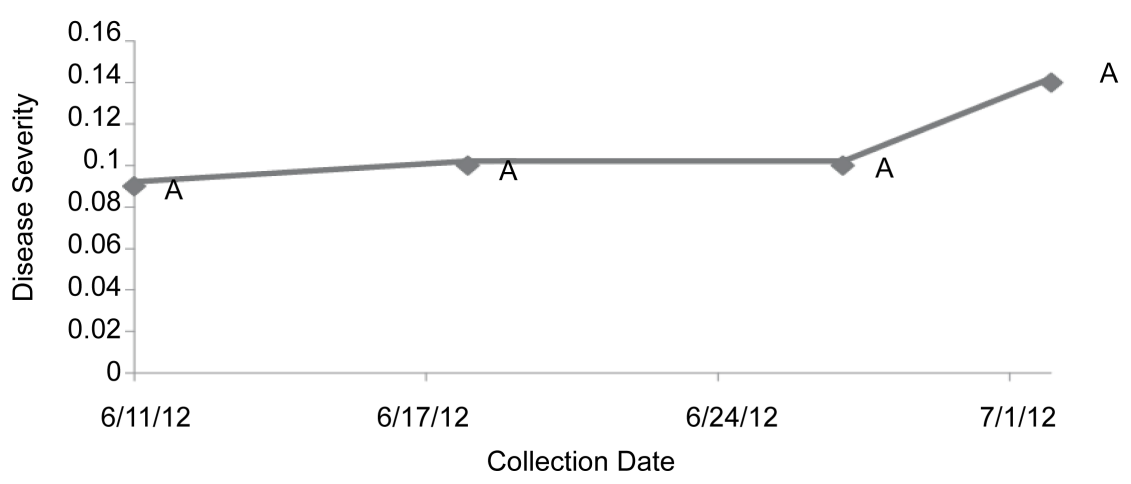

Figure 7. Disease severity in cotton bolls from the 2012 the Variety Trial $(P=0.5327)$.

highest level for the samples (Figure 7). In contrast to 2011, significant differences were not observed in the disease severity level among varieties $(\mathrm{P}=0.3237)$. Disease severity based on the disease ratings scale ranged from 0.06 to 0.15 between varieties.

Coastal Bend region (Wharton County, TX) producer survey. In 2011, boll rot was observed in $4 \%$ of the bolls collected during the single late season sampling (6 July 2011) from a Coastal Bend (Wharton County) field. During 2012, a total of 220 bolls were collected over 3 sampling events throughout the season. Boll rot reached $28 \%$ for the 14 August sample date (Table 2).

For the 2012 collection, significant differences were observed in the number of punctures per locule in the Coastal Bend field $(\mathrm{P}<0.1)$. Punctures per locule for the mid-June and mid-July collections were not statistically different. However, between the 18 July $(\mu=0.2)$ and 14 August $(\mu=3.6)$ collections the number of punctures per locule statistically increased (Figure 8 ). The increase could be due to a rise in sucking insect pest pressure in the fields.

Statistical differences were detected in the disease incidence from the Coastal Bend field collection for the 2012 season $(\mathrm{P}<0.1$, Figure 9). The August $(\mu=0.43)$ collection was significantly different from the earlier 26 June $(\mu=0.15)$ and 18 July $(\mu=0.7)$ collections, with a substantial increase in disease severity of 0.28 from July to August. Incidentally, the increased rot may be related to $3.5 \mathrm{~cm}$ of rainfall recorded in early July that provided moisture that is generally conducive to boll pathogen propagation.

Rio Grande Valley (Cameron and Willacy Counties, TX) producer survey. During 2011, disease was observed in the sample collections from the Rio Grande Valley fields with the highest incidence of $28 \%$ in June and dropping to $7 \%$ by the end of July (Table 3). Out of the 205 bolls collected in 2012, boll rot incidence reached 20\% (Table 3). Generally, boll rot incidence was detected for both seasons sampled.

There were no significant differences in punctures per locule observed in the Rio Grande Valley during the 2011 season ( $P=0.4652$, Figure 10). Still, an increase in the mean punctures per locule were observed in bolls of 0.94 between the 14 June $(\mu=0.1)$ and 20 July ( $\mu=1.04$ ) collections, followed by a mean decrease of 0.94 in punctures per locule on 28 July 2011 ( $\mu=0.1$, Figure 10 ).

Significant differences were observed in 2012 in mean punctures per locule through- 
Table 2. Texas Coastal Bend (Wharton County) boll damage and percent disease incidence.

\begin{tabular}{ccccc}
\hline Sample Date & Fields Sampled & Sample Size & $\begin{array}{c}\text { Bolls with Internal } \\
\text { Damage }\end{array}$ & Incidence* $^{*}$ \\
\hline $7 / 06 / 2011$ & 1 & 23 & 6 & $4 \%$ \\
$6 / 26 / 2012$ & 2 & 100 & 20 & $20 \%$ \\
$7 / 18 / 2012$ & 1 & 60 & 3 & $5 \%$ \\
$8 / 14 / 2012$ & 2 & 60 & 17 & $28 \%$ \\
\hline
\end{tabular}

${ }^{\star}$ Percent incidence determined by bolls with internal damage $\div$ sample size $\times 100$.

Table 3. Texas Rio Grande Valley (Cameron and Willacy Counties) boll damage and percent disease incidence.

\begin{tabular}{ccccc}
\hline Sample Date & Fields Sampled & Sample Size & $\begin{array}{c}\text { Bolls with Internal } \\
\text { Damage }\end{array}$ & Incidence $^{*}$ \\
\hline $6 / 14 / 2011$ & 2 & 121 & 34 & $28 \%$ \\
$7 / 20 / 2011$ & 1 & 42 & 7 & $17 \%$ \\
$7 / 28 / 2011$ & 1 & 44 & 3 & $7 \%$ \\
$6 / 06 / 2012$ & 3 & 45 & 4 & $9 \%$ \\
$6 / 19 / 2012$ & 3 & 60 & 12 & $20 \%$ \\
$7 / 03 / 2012$ & 2 & 40 & 8 & $20 \%$ \\
$7 / 16 / 2012$ & 2 & 60 & 7 & $12 \%$ \\
\hline
\end{tabular}

${ }^{*}$ Percent incidence determined by bolls with internal damage $\div$ sample size $\times 100$.

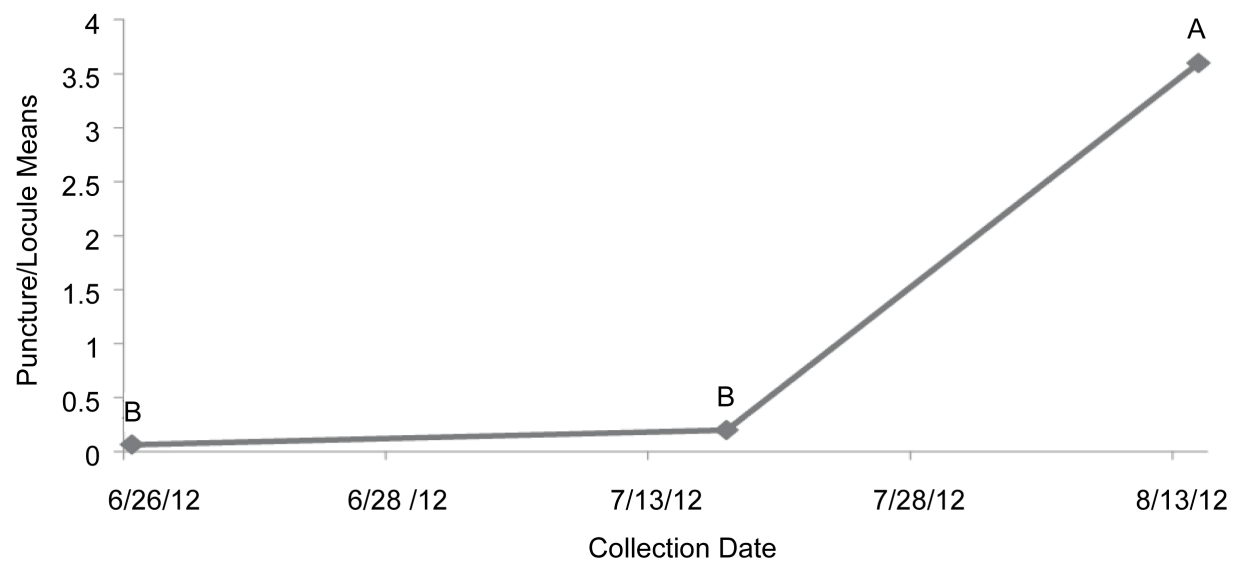

Figure 8. Cotton boll punctures per locule from the Texas Coastal Bend (Wharton County) in $2012(\mathrm{P}=0.0001)$.

out the Rio Grande Valley $(\mathrm{P}<0.1)$. In the same year, the mean punctures for the 16 July $(\mu=0.65)$ collection was significantly higher than from the 6 June $(\mu=0.043)$ and 19 June ( $\mu=0.133$ ) collections (Figure 11). This indicated that a steady influx of insects invaded the fields and thus, future boll rot work should consider concurrent sucking bug populations. 


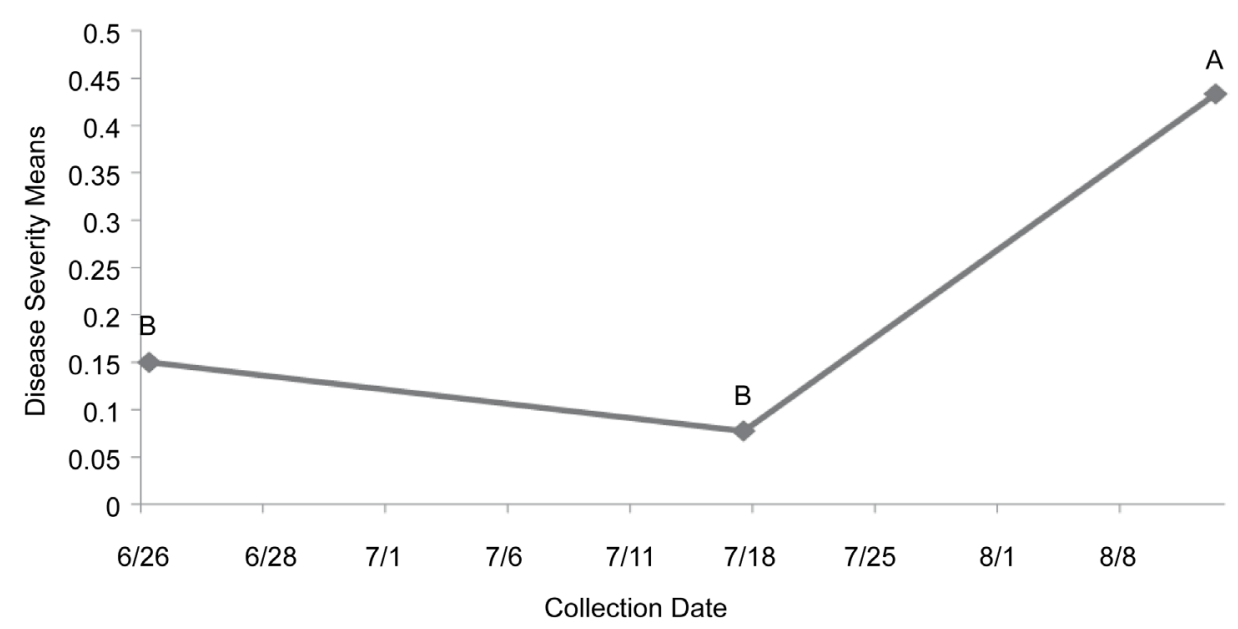

Figure 9. Disease severity in cotton bolls from the 2012 season in the Texas Coastal Bend (Wharton County) samples $(\mathrm{P}=0.0155)$.

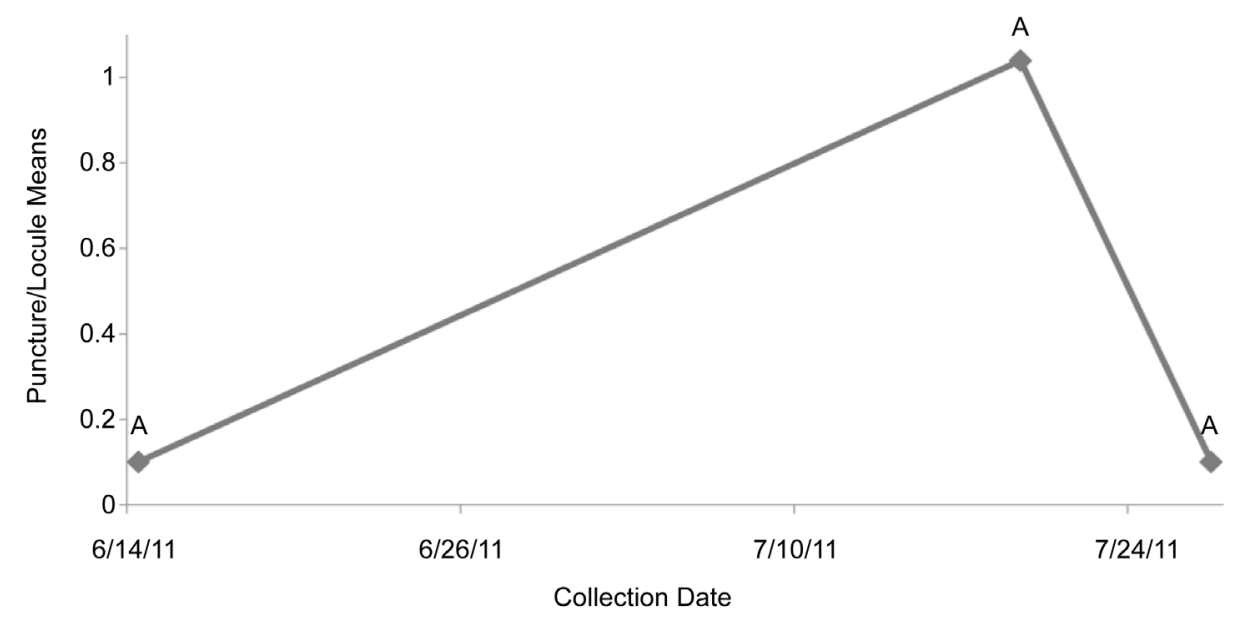

Figure 10. Cotton boll punctures per locule from the Texas Rio Grande Valley (Willacy and Cameron Counties) sampled in $2011(\mathrm{P}=0.4652)$.

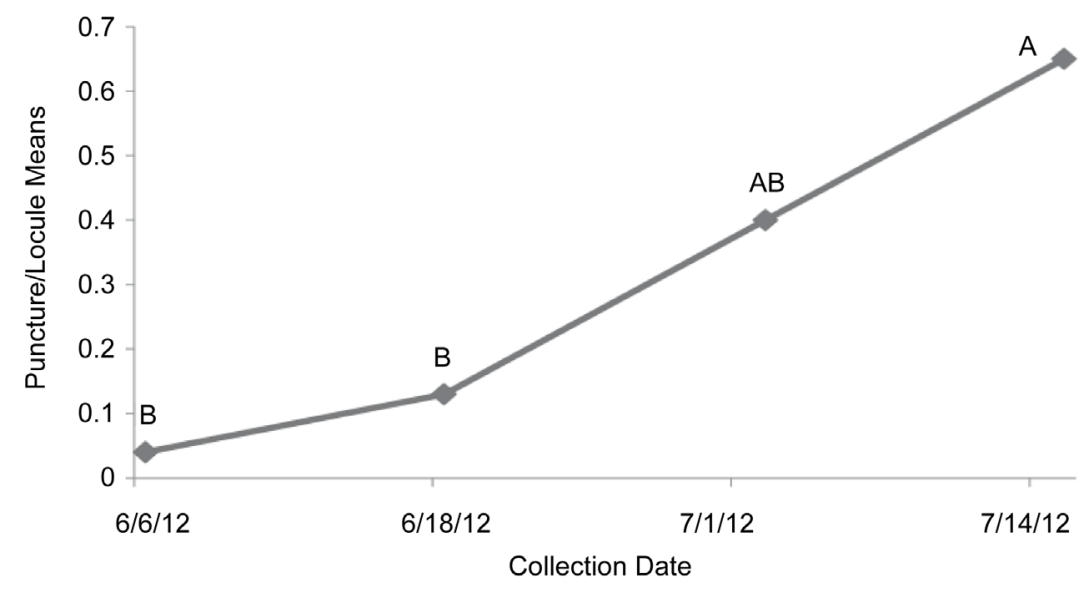

Figure 11. Cotton boll punctures per locule from the Texas Rio Grande Valley (Willacy and Cameron Counties) sampled in $2012(\mathrm{P}=0.1091)$. 
There were no significant differences observed in disease incidence among collection dates during 2011 ( $\mathrm{P}=0.4479)$. Regardless, there was a noticeable decrease in the number of diseased bolls midseason from the 20 July ( $\mu=1.14$ ) to the 28 July 2011 ( $\mu=$ 0.1 , Figure 12) collections.

In 2012, no significant differences were determined for disease occurrence in the Rio Grande Valley collections ( $\mathrm{P}=0.5464)$. However, there was a steady increase in the mean disease severity in locules from bolls sampled from 6 June to 3 July (Figure 13).

\subsection{Weather}

Boll rot was detected in all of the fields surveyed during both the 2011 and 2012 seasons despite limited rainfall. Water availability can impact plant vigor [21]-[25]. Thus, disease susceptibility may partially be attributed to boll rot differences between these two season studies. Drought conditions were endured in the Variety Trial in Kleberg County with a total annual rainfall of $7.2 \mathrm{~cm}$ and $16.1 \mathrm{~cm}$ recorded for 2011 and 2012,

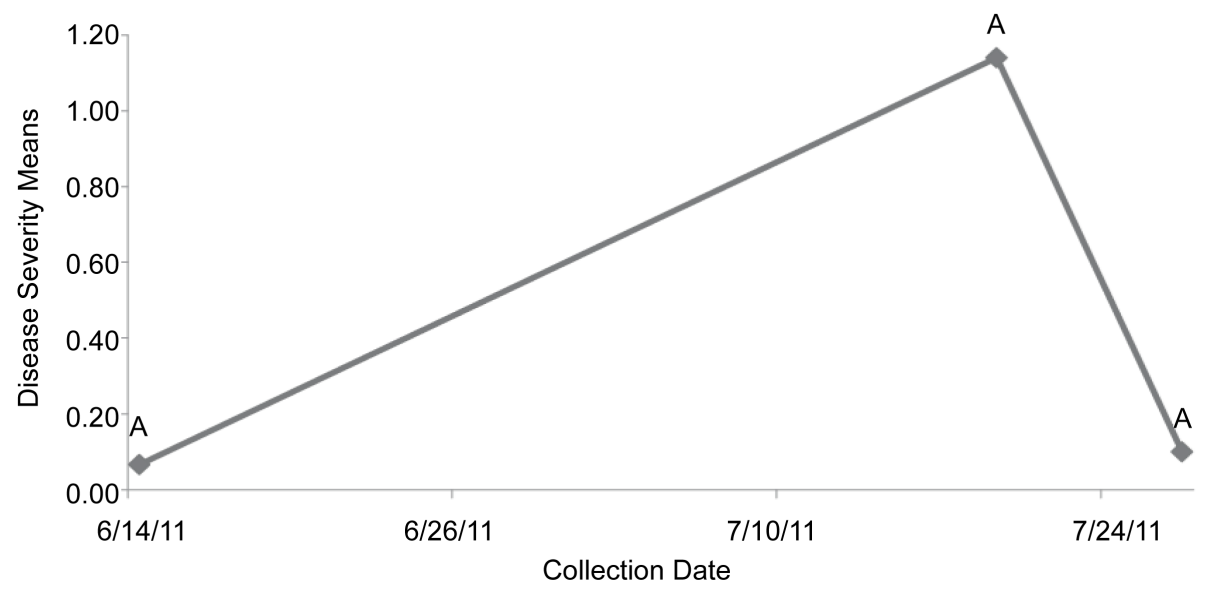

Figure 12. Disease severity in cotton bolls from the Texas Rio Grande Valley (Cameron and Willacy Counties) in $2011(\mathrm{P}=0.4479)$.

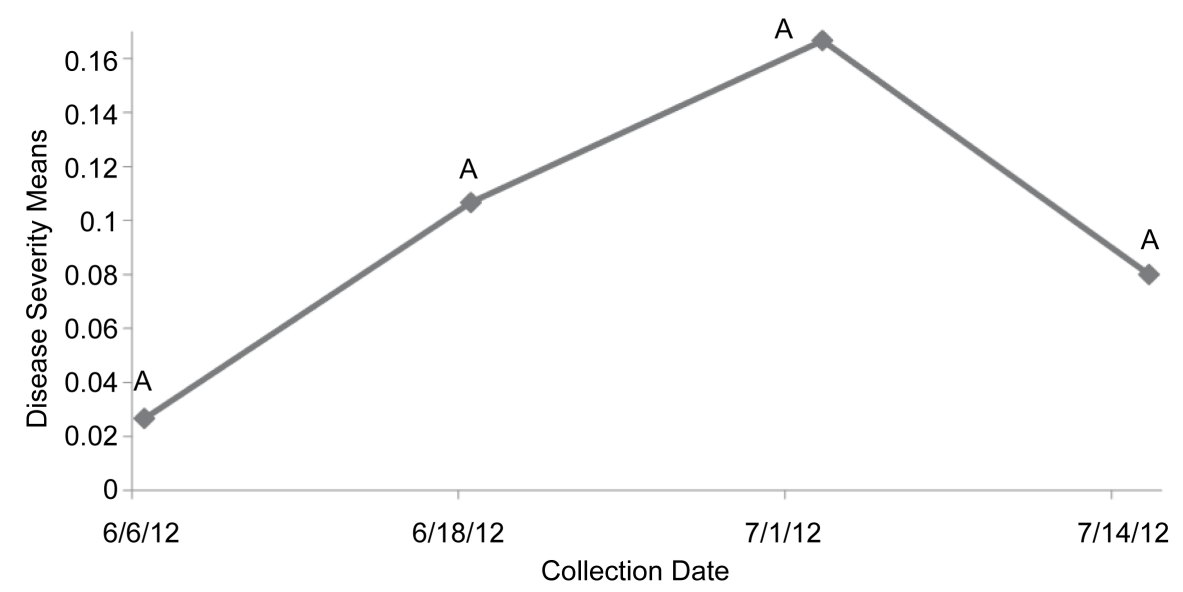

Figure 13. Disease severity in cotton bolls from the Texas Rio Grande Valley (Cameron and Willacy Counties) during $2012(\mathrm{P}=0.5464)$. 
respectively and likely impacted the stressed plants response to a pathogen challenge. During 2011 both the Coastal Bend and Rio Grande Valley regions also experienced drought conditions [26]. In 2012, climate conditions were classified as moderately moist for both south Texas regions [27] and may have had an effect in a relative increased incidence of disease from the year before.

Variety Trial-Kleberg County, TX research farm. A total of $7.2 \mathrm{~cm}$ of rainfall was measured from 1 March, 2011 to 31 August, 2011 that is almost $15.1 \mathrm{~cm}$ lower than normal average rainfall for that time period. In 2012, $16.1 \mathrm{~cm}$ of rainfall was recorded for the season [27]. This was a slight increase in rainfall compared to the year previous, but was still short of the normal expected precipitation of $22.6 \mathrm{~cm}$ over the same time period. A severe thunderstorm with $5.7 \mathrm{~cm}$ of recorded rainfall occurred on May 10, 2012. The storm produced sporadic hail resulting in severe plant damage and a developmental set back of 1 to 2 wks which could have affected disease susceptibility.

Coastal Bend region (Wharton County, TX) producer survey. In 2012, a total of $39.7 \mathrm{~cm}$ of rainfall was recorded for the Coastal Bend during the cotton growing season [27]. In 2012, heavy rainfall $(18.2 \mathrm{~cm})$ occurred throughout the month of July which may have attributed to increased boll rot incidences in the region.

Rio Grande Valley (Cameron and Willacy Counties, TX) producer survey. Typically, the Rio Grande Valley of Texas receives an average of $63.5-81.3 \mathrm{~cm}$ of rain annually [27]. A total of $10.1 \mathrm{~cm}$ of rainfall was recorded in the Rio Grande Valley from 1 March 2011 to 31 August 2011, almost $25.4 \mathrm{~cm}$ lower than normal [26]. In 2012, 18.8 $\mathrm{cm}$ of rainfall was recorded for the season. This was a slight increase in rainfall from the previous year, but still short of the expected $33.8 \mathrm{~cm} \mathrm{[27]} \mathrm{and} \mathrm{thus,} \mathrm{may} \mathrm{have} \mathrm{had} \mathrm{an}$ impact in the relatively low boll rot detected.

\subsection{Microorganism Characterization}

Based on the FAME analysis, bacterial isolates from the Variety Trial, and Coastal Bend and Rio Grande Valley boll surveys for both the 2011 and 2012 growing seasons consisted of a variety of bacterial genera. By far the majority of the isolates from the boll collections for both years were categorized as Bacillus spp. (Figure 14). Upon puncture inoculation of greenhouse bolls with these isolates, an inner boll disease with symptoms comparable to the field collected bolls occurred. Boll inoculations using water as the control resulted in the absence of disease symptoms with the inflicted effects comparable to Medrano and Bell [17].

Various putatively identified bacterial genera not typically considered plant pathogens were recovered from the boll collections including Alcaligenes, Kocuria, Salmonella, Staphylococcus, and Shewanella. Bacterial genera identified from the survey that are associated with cotton boll rot and were not consistently isolated consisted of Brevabacillus, Chryseomonas, Proteus, Citrobacter, Paenibacillus, Citrobacter, Coryenbacter, and Psychrobacter. Inoculations with representatives of the listed isolates resulted in various levels of boll disease. More detailed work on boll infections caused by the above listed isolates is ongoing. 


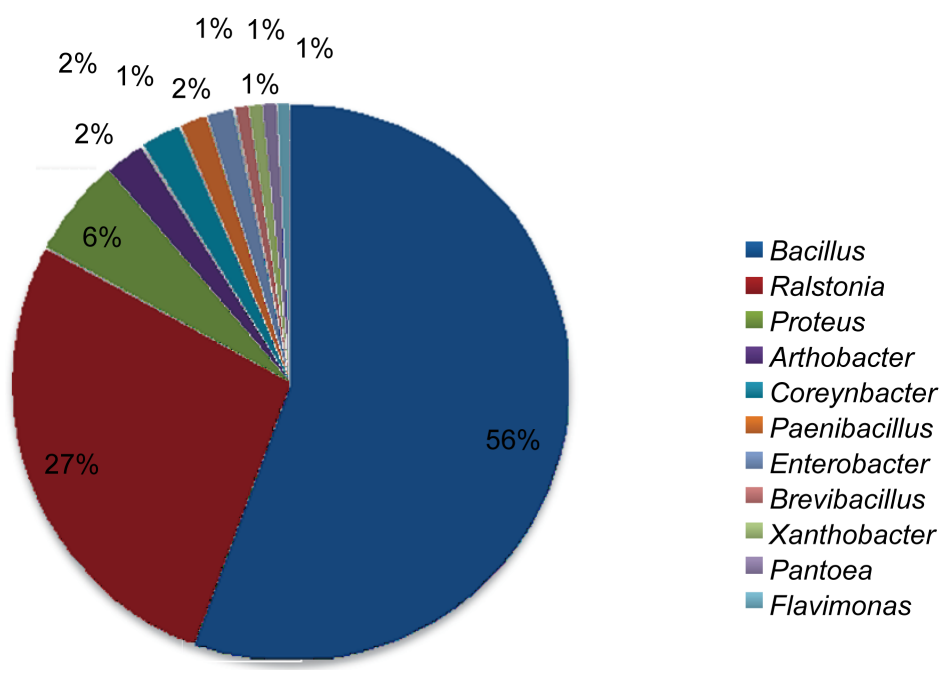

Figure 14. Distribution bacterial isolates recovered from diseased cotton bolls collected from south Texas fields during the 2011 and 2012 growing seasons.

\section{Conclusions}

The incidence of boll rot and disease severity was greater in 2011 than 2012 for the Variety Trial and the Rio Grande Valley collections. In August 2012, bolls from the Coastal Bend counties had the highest level of punctures per locule with a mean of 3.6 (Figure 8) and disease severity mean value of 0.45 (Figure 9). In 2012, the Variety Trial collection had the highest average number of punctures per locule with the mean value of 1.2 (Figure 4) and disease severity of 0.14 (Figure 7). Interestingly, the 16 July 2012 collection from the Rio Grande Valley counties had the highest average number of punctures per locule at 0.65 (Figure 11), yet, the average disease severity for that collection date was not correspondingly the highest. Instead, the maximum average disease severity for the collection date occurred on 3 July 2012 (Figure 13). The inconsistency in punctures and disease severity may be explained by the fact that although insects are pathogen vectors, those not harboring pathogens only limitedly damage bolls and disease will be absent [15]. Thus, a limitation of this work was that piercing-sucking insects were not collected to determine whether they harbored cotton boll pathogens.

Several bacterial isolates were associated with cotton boll rot in south Texas. However, Bacillus was the most prevalent bacterial genera identified in the south Texas collection areas during both 2011 and 2012 (Figure 14). Bacillus has been reported to be capable of inflicting boll rot previously [28]. Based on the results from this study, further research should be conducted to elucidate potential trends in the cause(s) of boll rot disease agents. A factor that likely affects cotton production that needs to be analyzed is populations of piercing-sucking cotton insect pests in the same regions. Brewer et al. [29] associated the Verde Plant Bug, Creontiades signatus, an emerging important sucking pest of cotton in south Texas with transmission of boll rot microorganisms. Also, previous research has reported that opportunistic strains of Pantoea agglomerans are vectored by sucking stink bugs into bolls causing inner boll rot [15] [30]. Collec- 
tively, the knowledge gained by this work and future research shall provide data to develop a predictive disease model that considers climate and pest populations to predict boll rot incidence and prevalence to properly consult producers.

\section{Acknowledgements}

Thanks to the cotton producers throughout the Texas Coastal Bend and Rio Grande Valley regions for granting access to their land for boll collections during the growing seasons. Thanks are also due to Jungmann Farms, Faske Brothers Farms, and Helena Chemical Co. in Robstown, TX for donating cotton seed, equipment, and guidance for the Variety Trial at the Texas A\&M University-Kingsville research farm.

\section{References}

[1] Fortucci, P. (2002) The Contributions of Cotton to Economy and Food Security in Developing Countries. World Cotton Research Conference Proceedings, Cairo, 20-25 October 2002, 1-5. https://www.icac.org/meetings/cgtn_conf/documents/11_fortucci.pdf

[2] Collins, G., Li, C. and Shurley, D. (2011) Cotton: Research-Extension Report. Journal of Cotton Science, 7, 1-88. http://www.ugacotton.com/vault/rer/2011/CottonRER2011.pdf

[3] Matocha, M., Allen, C., Bowman, R., Morgan, G. and Baumann, P. (2009) Crop Profile for Cotton in Texas. http://agrilife.org/aes/files/2010/06/Crop-Profile-for-Cotton-in-Texas2.pdf

[4] Nelson, C.T. (2016) National Cotton Council Survey Suggests US Producers to Plant 9.1 Million Acres in 2016. National Cotton Council. http://www.cotton.org/news/meetings/2016annual/plinten.cfm

[5] Hillocks, R.J. (Ed.) (1992) Cotton Diseases. Wallingford, CAB International Redwood Press, Melksham.

[6] Jones, G.H. (1928) An Alternaria Disease of the Cotton Plant. Annals of Botany, 42, 935947.

[7] Mitchell, P.L. (2004) Heteroptera as Vectors of Plant Pathogens. Neotropical Entomology, 33, 519-545. http://dx.doi.org/10.1590/S1519-566X2004000500001

[8] Schumann, G.L. and D’Arcy, C.J. (2010) Essential Plant Pathology. 2nd Edition, The American Phytopathological Society Press, St. Paul.

[9] Goldberg, S., Koenning, J.T., Pitts, J., Muller, M., Newman, J.E., Woodward, T., Wheeler, T. and Phipps, P. (2010) 2009 Cotton Disease Loss Estimate Committee Report. Proceeding of the Beltwide Cotton Conference, New Orleans, 4-7 January 2010, 237-240.

[10] Blassingame, D., et al. (2012) Cotton Disease Loss Estimate Report. Proceedings of the Beltwide Cotton Conference, Orlando, 3-6 January 2012, 341-244.

[11] Stewart, J.M.D. (2007) Boll Development and Seed Rot. Proceedings of the World Cotton Research Conference, Lubbock, 10-14 September 2007. http://wcrc.confex.com/wcrc/2007/techprogram/P1928.HTM

[12] Hudson, J. (2000) Seed Rot Hits South Carolina Cotton. Southeast Farm Press, USA. http://southeastfarmpress.com/seed-rot-hits-south-carolina-cotton

[13] Hollis, P. (2001) Seed Rot Has Lowered South Carolina Cotton Yields. Southeast Farm Press, USA. http://southeastfarmpress.com/mag/farming_seed_rot_lowered/

[14] Bell, A.A., Medrano, E.G., Lopez, J. and Esquivel, J.F. (2005) Identification and Frequency 
of Cottonseed-Rotting Bacteria Isolated from Stink Bugs in Texas. Phytopathology, 95, S8.

[15] Medrano, E.G., Esquivel, J.F. and Bell, A.A. (2007) Transmission of Cotton Seed and Boll Rotting Bacteria by the Southern Green Stink Bug (Nezaraviridula L.). Journal of Applied Microbiology, 103, 436-444. http://dx.doi.org/10.1111/j.1365-2672.2006.03262.x

[16] Ren, Y.Z., Liu, Y.Q., Ding, S.L., Li, G.Y. and Zhang, H. (2008) First Report of Cotton Caused by Pantoeaagglomerans in China. Plant Disease, 92, 1364. http://dx.doi.org/10.1094/PDIS-92-9-1364B

[17] Medrano, E.G., Esquivel, J.F., Bell, A.A., Greene, J., Roberts, P., Bacheler, J., Marois, J., Wright, D., Nichols, R. and Lopez, J. (2009) Potential for Nezara viridula (Hemiptera: Pentatomidae) to Transmit Bacterial and Fungal Pathogens into Cotton Bolls. Current Microbiology, 59, 405-412. http://dx.doi.org/10.1007/s00284-009-9452-5

[18] Medrano, E.G. and Bell, A.A. (2007) Role of Pantoea Agglomerans in Opportunistic Bacterial Seed and Boll Rot of Cotton (Gossypium hirsutum) Grown in the Field. Journal of Applied Microbiology, 102, 134-143. http://dx.doi.org/10.1111/j.1365-2672.2006.03055.x

[19] Sasser, M. (1990) Bacterial Identification by Gas Chromatographic Analysis of Fatty Acid Methyl Esters (GC-FAME). MIDI-Inc., Technical Note \#101. http://youngin.com/application/AN-0702-0013EN.pdf

[20] SAS Institute (2015) SAS/STAT 14.1 Software. SAS Institute Inc., Cary.

[21] Eaton, F. (1955) Physiology of the Cotton Plant. Annual Review Plant Physiology, 6, 299328. http://dx.doi.org/10.1146/annurev.pp.06.060155.001503

[22] Bauer, P.J. (1994) Cotton Crop Production. Encyclopedia of Agricultural Science, 1, 485493.

[23] Agrios, G.N. (2005) Plant Pathology. Elsevier Academic Press, London.

[24] Wright, D.L., Sprenkel, R.K. and Marois, J.J. (2009) Cotton Growth and Development. University of Florida IFAS Extension. http://edis.ifas.ufl.edu/pdffiles/AG/AG23500.pdf

[25] Cotton Incorporated (2015) Cotton Water Requirements. Nd. http://www.cottoninc.com/fiber/AgriculturalDisciplines/Engineering/Irrigation-Manageme nt/Cotton-Water-Requirements/

[26] NOAA (2012) Historical Palmer Drought Indices Palmer Z-Index. NOAA National Climatic Data Center.

https://www.ncdc.noaa.gov/temp-and-precip/drought/historical-palmers/overview

[27] NOAA (2013) Climate of 2013-April U.S. Palmer Drought Indices. NOAA National Climatic Data Center.

http://www.ncdc.noaa.gov/oa/climate/research/prelim/drought/palmer.html

[28] Bell, A.A., Medrano, E.G. and Lopez, J. (2008) Bacillus Seed and Boll Rot of Cotton: Symptoms and Transmission by Hemiptera. Phytopathology, 98, 521.

[29] Brewer, M.J., Armstrong, J.S., Medrano, E.G. and Esquivel, J. (2012) Association of Verde Plant Bug, Creontiades signatus (Hemiptera: Miridae), with Cotton Boll Rot. Journal of Cotton Science, 16, 144-151.

[30] Esquivel, J.F., Medrano, E.G. and Bell, A.A. (2010) Southern Green Stink Bugs (Hemiptera: Pentatomidae) as Vectors of Pathogens Affecting Cotton Bolls-A Brief Review. Southwestern Entomologist, 35, 457-461. http://dx.doi.org/10.3958/059.035.0332 
Submit or recommend next manuscript to SCIRP and we will provide best service for you:

Accepting pre-submission inquiries through Email, Facebook, LinkedIn, Twitter, etc. A wide selection of journals (inclusive of 9 subjects, more than 200 journals)

Providing 24-hour high-quality service

User-friendly online submission system

Fair and swift peer-review system

Efficient typesetting and proofreading procedure

Display of the result of downloads and visits, as well as the number of cited articles

Maximum dissemination of your research work

Submit your manuscript at: http://papersubmission.scirp.org/

Or contact as@scirp.org 